\title{
APLIKASI BERBAGAI BAHAN ZPT ALAMI UNTUK MENINGKATKAN PERTUMBUHAN BIBIT KEMIRI SUNAN (Reutealis trisperma (Blanco) Airy Shaw)
}

\section{APLICATION OF VARIOUS NATURAL PGRS TO INCREASE THE GROWTH OF CANDLENUT (Reutealis trisperma) CV SUNAN SEEDLING}

\author{
Fitri Kurniati, Tini Sudartini, dan Dikdik Hidayat \\ Jurusan Agroteknologi, Fakultas Pertanian Universitas Siliwangi \\ Jl. Siliwangi 24 Kota Tasikmalaya 46115 \\ Korespondensi : fitri.kurniati61@gmail.com
}

Diterima 26 April 2017 / Disetujui 29 Juli 2017

\begin{abstract}
ABSTRAK
Kemiri Sunan merupakan tanaman alternatif penyediaan bahan bakar nabati dan bahan baku berbagai produk industri. Kulit benih kemiri yang keras menjadi penghalang dalam perkecambahan. Kondisi ini dapat diperbaiki dengan pemberian zat pengatur tumbuh (ZPT) eksogen alami seperti umbi bawang merah sumber auksin, rebung bambu sumber giberelin, bonggol pisang dan air kelapa sebagai sumber sitokinin. Tujuan penelitian adalah mengetahui kemampuan berbagai bahan ZPT alami atau kombinasinya untuk menstimulasi perkecambahan dan pertumbuhan bibit kemiri sunan asal biji. Penelitian dilakukan pada bulan Juni sampai Oktober 2016, rancangan percobaan yaitu Rancangan Acak Kelompok yang diulang tiga kali, dengan perlakuan: a0 : kontrol (tanpa ZPT); a1 : ekstrak umbi bawang merah (BM); a2 : ekstrak rebung bambu (RB); a3: ekstrak bonggol pisang (BP); a4 : air kelapa (AK); a5: BM + RB; a6 : BM + BP; a7 : BM + AK; a8:RB+ BP; a9:RB+AK; a10 : BP+ AK; a11 : BM + $\mathrm{RB}+\mathrm{BP}+\mathrm{AK}$. Hasil penelitian menunjukkan pengaruh yang berbeda terhadap daya kecambah, tinggi bibit umur 30 hari setelah tanam (HST), 37 HST, 44 HST, dan 51 HST, juga jumlah daun pada 51 HST. Aplikasi zpt BP + AK menghasilkan daya kecambah paling baik $(97,78 \%)$, namun tidak berbeda dengan aplikasi $\mathrm{RB}+\mathrm{BP} ; \mathrm{BM}+\mathrm{RB}+\mathrm{BP}+\mathrm{AK} ; \mathrm{BM}+\mathrm{AK}$. Aplikasi zpt asal BP + AK menghasilkan tinggi bibit tertinggi $(13,57 \mathrm{~cm})$. Jumlah daun terbanyak dihasilkan pada aplikasi BP + AK (1,45 helai). Secara umum zpt bonggol pisang + air kelapa memberikan hasil paling baik, namun umbi bawang merah maupun rebung bambu mempunyai harapan untuk dikembangkan.
\end{abstract}

Kata kunci : air kelapa, bawang merah, bonggol pisang, kemiri sunan, rebung bambu

\begin{abstract}
Candlenut cv. Sunan is alternative biofuels plant also as raw of many industrial products. Its hard pulp seed becomes barrier of germination. This condition can be overcome by giving natural plant growth regulators (PGRs), i,e shallot as auxin source, bamboo shoot as gibberellin source, banana bulb and coconut water as sources of cytokinin. The research aim was knowing effect of various PGRs and their combinations to promote germination and growth of seedling candlenut cv Sunan. The research was done from June to October 2016, in experimental design
\end{abstract}


of Randomized Block Design (RBD), consisted of : $a 0$ : control (without PGRs); a1 : shallot (BM); a2 : bamboo shoot (RB); a3: banana bulb (BP); a4 : coconut water (AK); a5 : BM+ RB; a6 : BM + $B P ; a 7: B M+A K ; a 8: R B+B P ; a 9: R B+A K ; a 10: B P+A K ; a 11: B M+R B+B P+A K$, all repeated three times. The result showed that application of natural PGRs had significant effect on germination percentage, plant height on 30 days after planting (dap), 37 dap, 44 dap, and 51 dap, number of leaves 51 dap. Application of $B P+A K$ gave the best effect on germination (97.78\%), but no significant different with $R B+B P ; B M+R B+B P+A K$. Application of $B P+A K$ generated highest plant $(13.57 \mathrm{~cm})$. The best of the number of leaves was RB + AK $(1.45$ leaves). Overall application of natural PGRs from banana bulb + coconut water gave the best effect, besides bamboo shoot and shallot have opportunity to be developed.

Key words : banana bulb, bamboo shoot, candlenut cv sunan, coconut water, shallot

\section{PENDAHULUAN}

Kemiri sunan (Reutealis trisperma (Blanco) Airy Shaw) merupakan tanaman yang akan menjadi alternatif percepatan penyediaan bahan bakar nabati (BBN). Rendemen dari biji kemiri sunan bisa mencapai 50\%, dan dari minyak kasar dapat diperoleh $88 \%$ biodiesel dan $12 \%$ gliserol. Selain sebagai biodiesel dapat digunakan untuk memproduksi sabun, briket, pupuk organik, biopestisida, cat, resin, pelumas, kompos (Dirjen Perkebunan Kementrian Pertanian, 2013). Dalam rangka memperluas areal penanaman, perbaikan lahan kritis dan lahan marjinal, dibutuhkan bibit asal biji yang berkualitas dalam jumlah banyak, sehingga ketersediaan bibit menjadi tantangan masa kini.

Benih kemiri sunan merupakan biji yang berkulit keras, yang dapat menjadi penghalang dalam perkecambahan. Kadangkadang benih hanya tumbuh dengan persentase perkecambahan yang sangat kecil. Menurut llyas (2012), kondisi biji yang tidak tumbuh dengan kondisi yang optimal dikatakan sebagai benih yang tidah viabel. Kondisi ini dapat diperbaiki antara lain dengan pemberian zat pengatur tumbuh.

Zat Pengatur Tumbuh (ZPT) mutlak dibutuhkan tanaman, karena tanpa ZPT tidak akan terjadi pertumbuhan walaupun unsur hara memadai (Wareing dan Phillips, 1981). Selanjutnya dikatakan Salisbury dan Ross (1995), bahwa konsep ZPT diawali dengan konsep hormon, yaitu senyawa organik tanaman yang dalam konsentrasi rendah mempengaruhi proses fisiologis terutama diferensiasi dan perkembangan tanaman. Namun di dalam biji terkadang jumlahnya terbatas. Maka dapat diberikan ZPT eksogen sebagai perlakuan terutama pada perkecambahan. Selanjutnya Kurnianti (2002) mengungkapkan, bahwa ZPT eksogen berperan selayaknya ZPT endogen yang mampu menimbulkan rangsangan dan pengaruh pada tanaman, berlaku sebagai prekursor yaitu senyawa yang mendahului laju senyawa lain dalam proses metabolisme.

Menurut Nurlaeni dan Surya (2015), penggunaan ZPT eksogen sintetis belum banyak diaplikasikan oleh petani dan penggunakan ZPT alami merupakan alternatif yang mudah diperoleh di sekitar kita, relatif murah dan aman digunakan. Ada berbagai jenis atau bahan tanaman yang merupakan sumber ZPT, seperti bawang merah sebagai sumber auksin, rebung bambu sebagai sumber giberelin, dan bonggol pisang serta air kelapa sebagai sumber sitokinin (Lindung, 2014). Auksin, 
giberelin, dan sitokinin berinteraksi dalam menstimulasi pertumbuhan dan perkembangan tanaman, termasuk perkecambahan biji.

Auksin berfungsi dalam pengembangan sel, pertumbuhan akar, fototropisme, geotropisme, partenokarpi, apikal dominan, pembentukan kalus, respirasi (Abidin, 1993). Menurut Rismunandar (1999), pembentukan akar pada stek merupakan akibat kegiatan rizokalin, sedangkan rizokalin termasuk dalam kelompok auksin. ZPT eksogen pada kelompok auksin adalah IPA (Indole Propionic Acid) dan IBA (Indole Butiric Acid). Mekanisme kerja auksin yaitu mempengaruhi pelenturan dinding sel, sehingga air masuk secara osmosis dan memacu pemanjangan sel. Selanjutnya ada kerja sama antara auksin dan giberelin yang memacu perkembangan jaringan pembuluh dan mendorong pembelahan sel sehingga mendorong pembesaran batang (Rusmin, 2011). Kerja sama auksin dan sitokonin dengan konsentrasi 2,5 ppm dan 2,75 ppm dibuktikan oleh penelitian Tjokrowardojo et al. (2009) yang menunjukkan peningkatan persentase perkecambahan pada bibit Kamandrah (Croton tiglium L.) yaitu tanaman yang memiliki daya racun terhadap larva Aedes Aegypti.

Salah satu bahan tanaman yang dapat digunakan dalam pembibitan adalah filtrat bawang merah. Menurut Kusdijanto (1998), filtrat bawang merah mengandung ZPT yang mempunyai peranan mirip IAA (Asam Indole Asetat). Hasil penelitian Sudaryono dan Soleh (1994), menunjukkan bahwa bawang merah dapat digunakan untuk mempercepat pertumbuhan akar pada proses pencangkokan tanaman salak. Sedangkan penelitian Purwitasari (2004), menghasilkan pertumbuhan akar stek pucuk berbagai varietas krisan dengan pemberian perasan bawang merah konsentrasi 30\% selama 15 menit. Dikemukakan Ichsanudin (2014), bahwa perlakuan konsentrasi ekstrak umbi bawang merah terhadap bibit pepaya (Carica papaya L), menunjukkan bahwa konsentrasi ekstrak umbi bawang merah 15 $\mathrm{ml} \mathrm{L}^{-1}$ memberikan hasil tertinggi dibandingkan konsentrasi $5 \mathrm{ml} \mathrm{L}^{-1}, 10 \mathrm{ml} \mathrm{L}^{-1}$ dan $20 \mathrm{ml}$ $\mathrm{L}^{-1}$ pada parameter kecepatan berkecambah, daya kecambah, panjang akar, diameter batang, tinggi bibit, luas daun, berat segar dan berat kering bibit. Menurut Marfirani et al. (2014), pada bawang merah terdapat senyawa yang disebut allin yang kemudian akan berubah menjadi senyawa thiosulfinat seperti allicin. Allicin dengan thiamin (vitamin B) membentuk allithiamin yang memperlancar metabolisme pada jaringan tumbuhan.

Giberelin merupakan salah satu ZPT yang berpengaruh terhadap pembesaran tanaman, sehingga dikatakan bahwa kemampuan giberelin untuk meningkatkan pertumbuhan tanaman lebih kuat dibandingkan dengan auksin apabila diberikan secara tunggal. Peran lain dari giberelin adalah dalam perkecambahan, terutama dalam pemecahan dormansi. Mekanismenya yaitu setelah air diimbibisi, terjadi pelepasan giberelin dari embrio yang kerjanya mengaktifkan enzim-enzim yang berperan dalam memecah cadangan makanan dalam biji seperti amilase, protease, lipase. Bahan tersebut akan memberikan energi bagi perkembangan embrio diantaranya radikula yang akan mendobrak endosperm, kulit biji atau kulit buah yang menjadi faktor pembatas perkecambahan. Ini merupakan isyarat bahwa dormansi biji segera pecah dan biji segera berkecambah (Wareing dan Phillips, 1981). 
Walaupun giberelin terdapat pada biji namun untuk perkecambahan diperlukan pemberian giberelin eksogen untuk mengatasi kekurangan giberelin yang ada pada biji yang akan dikecambahkan. Bahan tanaman yang bisa dijadikan sebagai sumber giberelin adalah rebung bambu (Maretza, 2009; Mardaleni dan Sutriana, 2014). Penelitian Mardaleni dan Sutriana (2014) menunjukkan bahwa pemberian ekstrak rebung $4,5 \mathrm{ml} \mathrm{L}^{-1}$ air memberikan pengaruh baik terhadap tinggi, dan bobot polong kacang kacang hijau.

Sitokinin merupakan salah satu ZPT yang berperan dalam pembelahan sel. Sitokinin alami (kinetin, zeatin) dan beberapa sitokinin sintetik. Sitokinin alami dihasilkan pada jaringan yang tumbuh aktif terutama akar, embrio dan buah. Sitokinin dapat meningkatkan pertumbuhan dan perkembangan kultur sel. Peran sitokinin ini biasanya bekerja bersama-sama dengan auksin untuk menstimulasi pembelahan sel dan mempengaruhi lintasan diferensiasi (Abidin, 1993). Menurut Hartman (2002), permulaan terbentuknya akar tidak hanya dipengaruhi oleh ZPT auksin, tetapi juga oleh sitokinin dan giberelin dan sejumlah kofaktor pembentuk akar lainnya. Selanjutnya Abidin (1993) menyatakan apabila perbandingan konsentrasi sitokinin lebih besar daripada auksin, maka akan memperlihatkan pertumbuhan tunas dan daun, sebaliknya apabila konsentrasi sitokinin lebih kecil daripada auksin maka akan menstimulasi pembentukan kalus dan akhirnya terbentuk akar. Apabila konsentrasi sitokinin berimbang dengan konsentrasi auksin, maka pertumbuhan tunas, daun dan akar akan seimbang. Sitokinin juga berkerja sama dengan giberelin dalam peristiwa pemecahan dormansi biji.
Menurut Lindung (2014), sitokinin eksogen alami terdapat pada bonggol pisang. Namun pemanfaatan bonggol pisang sebagai sumber ZPT belum banyak digunakan masyarakat. Hasil penelitian Septari et al. (2013) menunjukkan bahwa pemberian ekstrak bonggol pisang meningkatkan tinggi tanaman padi varietas inpari. Sedangkan penelitian Jawal et al. (1991), menunjukkan bahwa pemberian sitokinin 2 ppm dan 4 ppm meningkatkan tinggi dan diameter tanaman. Bahan lain yang dapat digunakan sebagai sumber sitokinin adalah air kelapa. Dalam air kelapa muda terkandung hormon seperti sitokinin $5,8 \mathrm{~g} \mathrm{~L}^{-1}$ yang dapat merangsang pertumbuhan tunas dan mengaktifkan kegiatan sel hidup, hormon auksin 0,07 $\mathrm{mg} \mathrm{L}^{-1}$ dan sedikit giberelin serta senyawa lain yang dapat menstimulasi perkecambahan dan pertumbuhan (Bey et al., 2006).

Hasil penelitian Siahaan (2004), memperlihatkan bahwa penggunaan air kelapa muda sebagai ZPT dapat meningkatkan pertumbuhan dan produksi cabai merah. Penelitian lainnya menunjukkan bahwa air kelapa dapat meningkatkan hasil kedelai hingga $64 \%$, kacang tanah hingga $15 \%$, dan sayuran 20\%-30\%. Selain itu dengan kandungan unsur kalium yang tinggi, air kelapa dapat merangsang pembungaan pada anggrek dendrobium dan phalaenopsis. Penelitian lain yang dilakukan Ratnawati et al. (2013), menunjukkan bahwa perendaman bahan stek kakao dalam air kelapa selama 18 jam memberikan hasil yang tinggi. Juga penelitian Marlina, dan Anggraini (2002), menunjukkan persentase tumbuh $90 \%$ pada setek lada dengan perendaman air kelapa 50\% selama 12 jam. Selanjutnya Marpaung dan Hutabarat (2015) menunjukkan hasil penelitian bahwa air kelapa 50\% meng- 
hasilkan panjang tunas, jumlah daun, panjang akar, dan bobot basah akar lebih tinggi pada buah tin.

Pemberian beberapa jenis ekstrak tanaman (bonggol pisang, rebung dan campuran) sebagai zat pengatur tumbuh dan rasio amelioran terhadap pertumbuhan dan produksi padi varietas Inpari $12 \mathrm{di}$ Lahan Gambut (Septari et al., 2013), hasilnya menunjukkan bahwa ekstrak bonggol pisang menghasilkan tanaman yang lebih tinggi daripada rebung dan campurannya.

Tujuan penelitian adalah mengetahui kemampuan berbagai bahan zat pengatur tumbuh alami dan kombinasinya untuk menstimulasi perkecambahan dan pertumbuhan bibit kemiri sunan. Diduga bahwa zat pengatur tumbuh alami dan kombinasinya dapat menstimulasi perkecambahan dan pertumbuhan bibit kemiri sunan.

Hasil penelitian diharapkan dapat menjadi sumber informasi dalam pengembangan ilmu tanaman khususnya ekofisiologi tanaman, dan sebagai bahan ajar untuk mahasiswa. Secara praktis dapat dijadikan pedoman dalam memanfaatkan bahan zat pengatur tumbuh alami dalam proses perkecambahan dan pertumbuhan bibit kemiri Sunan.

\section{BAHAN DAN METODE}

Penelitian dilakukan pada bulan Juni 2016 sampai dengan Oktober 2016 menggunakan metode eksperimen dengan rancangan percobaan RAK sederhana dengan perlakuan berbagai bahan zpt alami sebagai berikut:

a0 : kontrol (tanpa bahan zpt), a1 : ekstrak umbi bawang merah, a2 : ekstrak rebung bambu, a3: ekstrak bonggol pisang; a4 : air kelapa, a5 : ekstrak umbi bawang merah + ekstrak rebung bambu, a6 : ekstrak umbi bawang merah + ekstrak bonggol pisang, a7 : ekstrak umbi bawang merah + air kelapa, a8 : ekstrak rebung bambu + ekstrak bonggol pisang, a9 : ekstrak rebung bambu + air kelapa, a10 : ekstrak bonggol pisang+ air kelapa, a11 : ekstrak umbi bawang merah + ekstrak rebung bambu + ekstrak bonggol pisang + air kelapa.

Keduabelas perlakuan diulang 3 kali sehingga terdapat 36 petak percobaan, masing-masing 20 benih. Untuk mengetahui perbedaan pengaruh perlakuan maka dilakukan pengujian dengan uji Fisher pada taraf kesalahan 5\%. Selanjutnya untuk mengetahui perlakuan terbaik, maka dilakukan uji Scott-Knott.

Bahan-bahan zat pengatur tumbuh difermentasikan dengan dekomposer MBIO selama 14 hari sebelum digunakan sampai terbentuk ekstrak. Kemudian pada pelaksanaannya digunakan konsentrasi $40 \mathrm{ml} \mathrm{L}^{-1}$. Selanjutnya adalah merendam biji bernas kemiri sunan dalam ekstrak bahan ZPT alami selama 24 jam. Kemudian menebar biji pada bak persemaian dan dilakukan pengamatan perkecambahan dan pertumbuhan pembibitan.

\section{HASIL DAN PEMBAHASAN}

\section{Pengamatan Utama}

Berdasarkan hasil analisis statistik, diketahui bahwa aplikasi berbagai zat pengatur tumbuh alami menunjukkan pengaruh yang berbeda terhadap daya kecambah, tinggi bibit umur 30 HST, 37 HST, 44 HST, dan 51 HST, jumlah daun umur 51 HST, namun tidak memberikan pengaruh terhadap bobot kering kecambah, bobot 
basah kecambah jumlah daun umur 44 HST (Tabel 1, Tabel 2, dan Tabel 3).

Perlakuan a10 menunjukkan daya kecambah paling baik, namun tidak berbeda dengan perlakuan a8, a11 dan a7. Sedangkan pada variabel tinggi tanaman umur 30 HST, 37 HST, 44 HST dan 51 HST, perlakuan kontrol menunjukkan bibit terendah sama dengan a2 dan a5. Pada Tabel 3 nampak bahwa aplikasi ekstrak bahan zat pengatur tumbuh alami berpengaruh terhadap jumlah daun bibit kemiri sunan umur 51 HST, tapi tidak berpengaruh terhadap jumlah daun umur 44 HST.

Tabel 1. Pengaruh aplikasi zat pengatur tumbuh alami terhadap daya kecambah, bobot basah kecambah (g), dan bobot kering kecambah (g) kemiri sunan

\begin{tabular}{|c|c|c|c|c|}
\hline $\begin{array}{c}\text { Perlakuan } \\
\text { Ekstrak Tanaman Sebagai Sumber ZPT }\end{array}$ & $\begin{array}{l}\text { Daya } \\
\text { Kecambah }\end{array}$ & \multicolumn{2}{|c|}{$\begin{array}{c}\text { Bobot Basah } \\
\text { Kecambah }\end{array}$} & $\begin{array}{l}\text { Bobot Kering } \\
\text { Kecambah }\end{array}$ \\
\hline & $---\%-$ & \multicolumn{3}{|c|}{--g-- } \\
\hline a0 : kontrol (tanpa bahan zpt) & 37,78 a & \multicolumn{2}{|c|}{$5,79 a$} & $1,41 \mathrm{a}$ \\
\hline a1 : umbi bawang merah & 57,78 a & \multicolumn{2}{|c|}{$7,00 \mathrm{a}$} & $1,80 \mathrm{a}$ \\
\hline a2 : rebung bambu & $42,22 a$ & \multicolumn{2}{|c|}{$4,81 \mathrm{a}$} & $1,01 \mathrm{a}$ \\
\hline a3 : bonggol pisang & $55,56 a$ & \multicolumn{2}{|c|}{$8,67 a$} & $2,24 \mathrm{a}$ \\
\hline a4 : air kelapa & $73,33 \mathrm{~b}$ & \multicolumn{2}{|c|}{$8,43 \mathrm{a}$} & $1,97 \mathrm{a}$ \\
\hline a5 : umbi bawang merah + rebung bambu & 53,33 a & \multicolumn{2}{|c|}{$9,13 \mathrm{a}$} & $2,20 \mathrm{a}$ \\
\hline a6 : umbi bawang merah + bonggol pisang & 55,56 a & \multicolumn{2}{|c|}{$6,91 \mathrm{a}$} & $1,78 \mathrm{a}$ \\
\hline a7 : umbi bawang merah + air kelapa & $68,89 \mathrm{~b}$ & \multicolumn{2}{|c|}{$7,24 a$} & $1,85 \mathrm{a}$ \\
\hline a8 : rebung bambu + bonggol pisang & $75,56 \mathrm{~b}$ & \multicolumn{2}{|c|}{$9,24 a$} & $2,59 a$ \\
\hline a9: rebung bambu + air kelapa & 62,22 a & \multicolumn{2}{|c|}{10,08 a } & $2,75 \mathrm{a}$ \\
\hline a10: bonggol pisang+ air kelapa & $97,78 b$ & \multicolumn{2}{|c|}{$10,60 \mathrm{a}$} & $2,94 \mathrm{a}$ \\
\hline $\begin{array}{l}\text { a11 : umbi bawang merah + rebung } \\
\text { bambu + bonggol pisang + air kelapa }\end{array}$ & $73,33 \mathrm{~b}$ & \multicolumn{2}{|c|}{$9,88 \mathrm{a}$} & $2,51 \mathrm{a}$ \\
\hline \multicolumn{5}{|c|}{$\begin{array}{c}\text { Keterangan : Angka rata-rata yang diikuti oleh huruf yang sama tidak berbeda nyata menurut uji Scott } \\
\text { Knott }\end{array}$} \\
\hline \multirow{2}{*}{$\begin{array}{c}\text { Perlakuan } \\
\text { (Ekstrak tanaman sebagai sumber ZPT) }\end{array}$} & \multicolumn{4}{|c|}{ Tinggi bibit } \\
\hline & $30 \mathrm{HST}$ & $37 \mathrm{HST}$ & $44 \mathrm{HST}$ & $51 \mathrm{HST}$ \\
\hline$--\mathrm{ml} \mathrm{L}^{-1}--$ & \multicolumn{4}{|c|}{$--\mathrm{cm}--$} \\
\hline $\mathrm{a} 0$ : kontrol (tanpa zpt) & $3,72 \mathrm{a}$ & 7,49 a & $8,70 \mathrm{a}$ & $10,92 \mathrm{a}$ \\
\hline a1 : umbi bawang merah & $4,84 \mathrm{~b}$ & $9,06 \mathrm{~b}$ & $9,96 \mathrm{~b}$ & $12,70 \mathrm{~b}$ \\
\hline a2 : rebung bambu & $4,36 a$ & $8,20 \mathrm{a}$ & $9,51 \mathrm{a}$ & 11,63 a \\
\hline a3 : bonggol pisang & $4,76 \mathrm{~b}$ & $9,02 \mathrm{~b}$ & $9,99 \mathrm{~b}$ & $12,28 \mathrm{~b}$ \\
\hline a4 : air kelapa & $5,07 \mathrm{~b}$ & $9,17 \mathrm{~b}$ & $10,31 \mathrm{~b}$ & $12,54 \mathrm{~b}$ \\
\hline a5 : umbi bawang merah + rebung bambu & $4,42 \mathrm{a}$ & $8,20 \mathrm{a}$ & $9,78 b$ & $11,51 \mathrm{a}$ \\
\hline a6 : umbi bawang merah + bonggol pisang & $4,61 \mathrm{~b}$ & $8,95 \mathrm{~b}$ & $10,29 \mathrm{~b}$ & $12,08 \mathrm{~b}$ \\
\hline a7 : umbi bawang merah + air kelapa & $5,02 \mathrm{~b}$ & $9,24 b$ & $10,10 \mathrm{~b}$ & $12,82 \mathrm{~b}$ \\
\hline a8 : rebung bambu + bonggol pisang & $5,05 b$ & $9,19 \mathrm{~b}$ & $10,12 b$ & $12,41 \mathrm{~b}$ \\
\hline a9 : rebung bambu + air kelapa & $5,00 \mathrm{~b}$ & $8,90 \mathrm{~b}$ & $9,97 b$ & $12,14 b$ \\
\hline a10 : bonggol pisang+ air kelapa & $5,23 \mathrm{~b}$ & $10,04 \mathrm{~b}$ & $11,04 \mathrm{~b}$ & $13,57 b$ \\
\hline $\begin{array}{l}\text { a11 : umbi bawang merah + rebung } \\
\text { bambu + bonggol pisang + air kelapa }\end{array}$ & $4,95 \mathrm{~b}$ & $9,68 b$ & $10,08 \mathrm{~b}$ & $12,49 \mathrm{~b}$ \\
\hline
\end{tabular}

Keterangan : Angka rata-rata yang diikuti oleh huruf yang sama tidak berbeda nyata menurut uji Scott Knott 
Pengaruh yang ada pada berbagai variabel pengamatan disebabkan kandungan ZPT yang terdapat pada bahan yang digunakan. Hasil pengujian di Laboratorium Environmental Biotechnology Laboratory, Indonesian Center for Biodiversity and Biotechnology (ICBB), 2016 menunjukkan bahwa per $100 \mathrm{ml}$ ekstrak bonggol pisang mengandung sitokinin berupa zeatin 2,411 ppm dan kinetin 3,620 ppm. Demikian juga air kelapa per $100 \mathrm{ml}$ mengandung sitokinin berupa zeatin 3,122 ppm dan kinetin 4,557 ppm. Sementara itu per $100 \mathrm{ml}$ ekstrak rebung bambu mengandung giberelin 8,116 ppm dan per $100 \mathrm{ml}$ ekstrak bawang merah mengandung auksin sebanyak 10,355 ppm yang berupa IAA. Penelitian Suparjo et al. (2016), menunjukkan pengaruh IAA terhadap tinggi tunas dan jumlah daun Binahong dengan melalui perbanyakan mikro.

Tabel 3. Pengaruh Aplikasi ZPT Alami terhadap Jumlah Daun Bibit Kemiri Sunan

\begin{tabular}{lcc}
\hline \multirow{2}{*}{ Perlakuan } & \multicolumn{2}{c}{ Jumlah Daun } \\
\cline { 2 - 3 } (Ekstrak tanaman sebagai sumber ZPT) & 44 HST & $51 \mathrm{HST}$ \\
\hline a0 : kontrol (tanpa zpt) & & --helai-- \\
a1 : umbi bawang merah & $0,42 \mathrm{a}$ & $1,00 \mathrm{a}$ \\
a2 : rebung bambu & $0,62 \mathrm{a}$ & $1,22 \mathrm{a}$ \\
a3 : bonggol pisang & $0,51 \mathrm{a}$ & $1,09 \mathrm{a}$ \\
a4 : air kelapa & $0,60 \mathrm{a}$ & $1,20 \mathrm{a}$ \\
a5 : umbi bawang merah + rebung bambu & $0,82 \mathrm{a}$ & $1,38 \mathrm{~b}$ \\
a6 : umbi bawang merah + bonggol pisang & $0,64 \mathrm{a}$ & $1,22 \mathrm{a}$ \\
a7 : umbi bawang merah + air kelapa & $0,75 \mathrm{a}$ & $1,24 \mathrm{a}$ \\
a8 : rebung bambu + bonggol pisang & $0,75 \mathrm{a}$ & $1,33 \mathrm{~b}$ \\
a9 : rebung bambu + air kelapa & $0,78 \mathrm{a}$ & $1,33 \mathrm{~b}$ \\
a10 : bonggol pisang+ air kelapa & $0,51 \mathrm{a}$ & $1,20 \mathrm{a}$ \\
a11 : umbi bawang merah + rebung bambu + & $0,91 \mathrm{a}$ & $1,45 \mathrm{~b}$ \\
bonggol pisang + air kelapa & $0,67 \mathrm{a}$ & $1,26 \mathrm{a}$ \\
\hline
\end{tabular}

Keterangan : Angka rata-rata yang diikuti oleh huruf yang sama tidak berbeda nyata menurut uji ScottKnott

Penggabungan dua atau lebih zat pengatur tumbuh akan memberikan efek yang saling menguatkan. Seperti dikatakan Hartman (2002), bahwa permulaan terbentuknya akar tidak hanya dipengaruhi oleh zat pengatur tumbuh auksin, tetapi juga dipengaruhi oleh sitokinin dan giberelin dan sejumlah kofaktor pembentuk akar lainnya. Sementara itu menurut Abidin (1993), apabila perbandingan konsentrasi sitoknin lebih besar daripada auksin, maka akan memperlihatkan pertumbuhan tunas dan daun. Sitokinin juga bekerja sama dengan giberelin dalam peristiwa pemecahan dormansi.

Pengaruh air kelapa juga dibuktikan melalui penelitian Ratnawati et al. (2013), yang menunjukkan bahwa perendaman bahan setek kakao dalam air kelapa selama 18 jam memberikan hasil setek yang tinggi. Sementara itu penelitian Septari, et al. (2013) menunjukkan bahwa pemberian ekstrak bonggol pisang berpengaruh lebih baik daripada rebung dan campurannya terhadap tinggi tanaman padi varietas Inpari 12 di Lahan Gambut. 
Rebung bambu memberikan pengaruh baik terhadap tinggi tanaman dan jumlah daun umur $51 \mathrm{HST}$, Ini membuktikan bahwa giberelin mempunyai peran dalam perkecambahan. Rebung bambu dikaitkan dengan kandungan giberelin yang relatif tinggi. Seperti hasil penelitian Mardaleni dan Sutriana (2014), bahwa pemberian ekstrak rebung bambu $4,5 \mathrm{ml} \mathrm{L}^{-1}$ air memberikan pengaruh baik terhadap tinggi, dan bobot polong kacang hijau.

\section{Pengamatan Penunjang}

Berdasarkan pengamatan pendahuluan, nampak bahwa mutu benih kemiri sunan seringkali belum menjadi perhatian pengumpul. Penjual benih lebih banyak mengumpulkan biji-biji kemiri dari berbagai sumber. Pengumpulan benih dari sumber tanaman liar juga akan mengabaikan kematangan benih. Padahal masak fisiologi merupakan stadia pertumbuhan penting bagi tanaman, karena akan berhubungan dengan akumulasi maksimum berat kering benih. Walaupun benih yang belum masak dapat berkecambah, namun vigornya rendah. Setelah mencapai maksimum, mutu benih akan mengalami penurunan sejalan dengan waktu, disebut kemunduruan benih (seed ageing) (Tjokrowardojo et al., 2009).

Pengamatan penunjang dilakukan terhadap daya kecambah secara cepat yaitu dengan Uji Tetrazolium. Pada umumnya uji ini digunakan terhadap tanaman keras dengan biji yang keras pula karena pada biji tersebut kebanyakan tidak bersertifikat, sehingga diragukan perkecambahannya, termasuk juga kemiri sunan. Benih yang direndam pada larutan tetrazolium akan menunjukkan perubahan warna sesuai dengan kondisi benih, ada yang merah, merah jambu, atau tetap putih. Garam tetrazolium merupakan bahan tidak berwarna dan di dalam sel hidup zat ini ikut serta dalam proses reduksi, sehingga menghasilkan warna jelas pada sel hidup, sedangkan pada sel mati tetap berwarna putih. Menurut Dina et al. (2007), uji tetrazolium dapat mendeteksi kerusakan paling dini pada embrio dan menunjukkan deteriorasi benih yang merupakan indikator vigor, sehingga seharusnya berkorelasi dengan pertumbuhan tanaman.

Berdasarkan hasil uji tetrazolium pada setiap perlakuan, maka dapat dilihat bahwa benih yang berwarna merah tua (jaringan rusak) dengan persentase tertinggi terdapat pada perlakuan a0 (kontrol) yaitu $8,86 \%$, sementara pada perlakuan lainnya hanya terdapat pada a2 (rebung bambu) dan a6 (bawang merah + bonggol pisang) dengan nilai masing-masing 2,22\%.

Kemunduran benih tanaman disebabkan oleh banyak faktor. Dikatakan oleh Ilyas (2012), bahwa kemunduruan benih dipengaruhi oleh berbagai faktor, diantaranya komposisi bahan kering biji, cara mengumpulkan, dan penyimpanan. Tuntutan terhadap mutu benih yang kompleks nampaknya belum dapat terpenuhi semua oleh pengumpul dengan berbagai keterbatasan, sehingga akhirnya benih yang ditanam tidak dapat berkecambah. Faktor lain adalah tingginya kadar etanol pada biji kemiri sunan. Menurut llyas (2012), kandungan etanol dalam benih jagung menurunkan viabilitas benih secara nyata. Kemunduran viabilitas oleh keracunan etanol menurunkan aktivitas enzim $\alpha$-amilase, dehidrogenase dan peroksidase. Sementara itu kemiri sunan mengandung etanol dengan kadar tinggi sehingga benih tidak mampu berkecambah. 


\section{KESIMPULAN}

1. Aplikasi berbagai ekstrak sebagai sumber ZPT alami memberikan pengaruh terhadap daya kecambah, tinggi bibit umur 30 HST, 37, 44 HST, 51 HST, dan jumlah daun 51 hari HST pada kemiri sunan.

2. Aplikasi ekstrak bonggol pisang sebagai sumber ZPT dicampur air kelapa memberikan hasil paling baik terhadap semua variabel yang diamati.

3. Ekstrak rebung bambu dan ekstrak umbi bawang merah mempunyai potensi untuk diaplikasikan pada benih untuk mendapatkan bibit kemiri sunan yang baik.

\section{DAFTAR PUSTAKA}

Abidin, Z 1993. Dasar-dasar Pengetahuan Tentang Zat Pengatur Tumbuh. Penerbit Angkasa Bandung.

Bey, Y, Syafri W dan Sutrisna, 2006. Pengaruh Pemberian Giberelin (GA3) dan Air Kelapa terhadap Perkecambahan Biji Anggrek Bulan. Jurnal Biogenesis 2(2): 41-46.

Dina, E.W., Baran, W.,dan Satriyas I. 2007. Pola Topografi Pewarnaan Tetrazolium sebagai Tolok Ukur Viabilitas dan Vigor Benih Kedelai (Glycine max L. Merr.) untuk Pendugaan Pertumbuhan Tanaman di Lapangan. Jurnal Agronomy Indonesia. Vol 35 (2).

Dirjen Perkebunan Kementrian Pertanian, 2013. Peningkatan Produksi, Produktivitas, dan Mutu Tanaman Tahunan. Pedoman Teknis Pengembangan Tanaman Kemiri Sunan.

Hartman, H.T., Kester, D.E., dan Davies, F.T. 2002. Plant Propagation. Principles and
Practices $7^{\text {th }}$ ed. Pearson Education INC. New Jersey.

Ichsanudin, F.N. 2014. Pengaruh Konsentrasi Jus Umbi Bawang Merah terhadap Perkecambahan dan Pertumbuhan Awal Bibit Carica papaya. UNS Digital Library. Penerjemah Herawati Susilo. Jakarta : Universitas Indonesia Press.

Ilyas, S. 2012. Ilmu dan Teknologi Benih. Teori dan Hasil-hasil Penelitian. Bogor. PT. Penerbit IPB Press.

Jawal, M.A., Ismiati, dan Sugito. 1991. Stimulasi Pertumbuhan Manggis (Garcinia mangostana L.). Jurnal Hortikultura 2 : 8-12.

Repository.ipb.ac.id/jspui/bitstream/ 123456789/.../6/ Daftar\%20Pustaka_2007liz-6.pdf.

Kurnianti, N. 2002. Hormon Tumbuhan atau Zat Pengatur Tumbuh. http//www.tanijogonegoro.com/2012/h ormone-tumbuhan-atau-zpt-zatpengatur.html. Diakses tanggal 24 Desember 2014.

Lindung. 2014. Teknologi Aplikasi Zat Pengatur Tumbuh. Balai Pelatihan Pertanian . Jambi.

Mardaleni dan Sutriana, S. 2014. Pemberian Ekstrak Rebung dan Pupuk Hormon Tanaman Unggul terhadap Pertumbuhan dan Produksi Kacang Hijau (Vigna radiata L.) Jurnal Dinamika Pertanian. Volume XXIX. (1)

Maretza, D. T. 2009. Pengaruh Dosis Ekstrak Rebung Bambu Betung terhadap Pertumbuhan Semai Sengon (Paraserianthes falcataria (L.). Laporan Penelitian Institut Petanian Bogor.

Marfirani, M., Yuni, S. R., dan Evie, R. 2014. Pengaruh Berbagai Konsentrasi Filtrat Umbi Bawang Merah dan Rootone $\mathrm{F}$ terhadap Pertumbuhan Stek Melati 
“Rato Ebu. Universitas Negeri Surabaya. Lentera Bio Volume 3 (1).

Marlina, L. R dan Angraini, N. 2002. Respon Setek Lada (Piper nigrum L.) terhadap Pemberian Zat Pengatur Tumbuh Alami Nabati. Majalah Sriwijaya Volume 35 (3) Desember.

Marpaung, A.E. dan Hutabarat, R.C. 2015. Respons jenis Perangsang Tumbuh Berbahan ALami dan Asal Stek Batang terhadap Pertumbuhan Bibit Tin (Ficus carica L). Jurnal Hortikultura. 25(1) : 37 43.

Nurlaeni, Y. dan Surya, M. I. 2015. Respon Stek Pucuk Camelia japonica terhadap Pemberian Zat Pengatur Tumbuh Organik. Prosiding Seminar Nasional Masyarakat Biodiversifikasi Indonesia. Volume 1 Nomor 5 Agustus 2015. Halaman 1211-1215.

Purwitasari, W. 2004. Pengaruh Perasan Bawang Merah (Allium ascalonicum L.) terhadap Pertumbuhan akar Stek Pucuk Krisan (Chrysanthemum sp.) http/eprint.undip.ac.id./29654/ Diunduh 7 Maret 2015.

Ratnawati, Sukemi, I.S., dan Sri. Y. 2013. Waktu Perendaman Benih Dengan Air Kelapa Muda terhadap Pertumbuhan Bibit Kakao (Theobroma cacao L.). Universitas Riau. http://download.portal garuda.org/article.ptip\%

Rusmin, D. 2011. Pengaruh Pemberian GA3 Pada Berbagai Konsentrasi dan Lama Inbibisi Terhadap Peningkatan Viabilitas Benis Puwoceng (Pimpinella pruatjan Molk.). Jurnal Littri. Vol: 17. No: 3

Salisbury, FB, Ross, C.W, 1995. Fisiologi Tumbuhan Jilid 3. Penerjemah Lukman, Sumaryono. Penerbit ITB Press. Bandung

Septari, Y., Nelvia, dan Al, I.A. 2013. Pengaruh Pemberian Beberapa Jenis Ekstrak Tanaman Sebagai ZPT dan Rasio Amelioran terhadap Pertumbuhan dan
Produksi Padi Varietas Inpari 12 di Lahan Gambut. Jurnal Dinamika Pertanian. Universitas Riau.

Siahaan. 2004. Pengaruh Konsentrasi Air Kelapa Muda terhadap Pertumbuhan Produksi Cabai Merah (Capsicum annum L). Fakultas Pertanian Universitas Riau.

Sudaryono, T. dan Soleh, M. 1994. Induksi Akar pada Perbanyakan Salak Secara Vegetatif. Jurnal Penelitian Hortikultura, Vol 6 No. 2 hal 1-12

Suparjo, Juwartina, I.R., Syofi, R., Teuku, T., dan Ahmad, R. 2016. Pengaruh Auksin dan Sitokinin terhadap Perbanyakan Mikro Tanaman Binahong (Anredera cordifolia (Tenore) Steenis). Jurnal Bioteknologi dan Biosains Indonesia, Volume 3 (2).

Tjokrowardojo, A.S., Rosman, R., dan Pradono, D.I. 2009. Pengaruh Zat Pengatur Tumbuh terhadap Perkecambahan Benih dan Pertumbuhan Bibit Kamarandah (Croto tiglium L.). Jurnal Agrotropika 14(2): 55-60.

Wareing, P.F. dan I.D.J. Phillips. 1981. The Control of Growth and Differentiation in Plants. Pergamon Press. New York. 